\title{
FLOWER COLOUR POLYMORPHISM IN CIRSIUM PALUSTRE 1
}

\author{
D. J. MOGFORD \\ The Botany School, South Parks Road, Oxford OXI 3RA
}

Received 17.xii.73

\begin{abstract}
SUMmaRY
In seacliff and mountain populations the thistle Cirsium palustre (L.) Scop. is polymorphic for flower colour, occurring as the typical purple flowered morph, a white flowered morph, and two intermediate flowered morphs. The white morphs are homozygous. The polymorphism is subject to selective forces associated with exposure and fluctuation in population size. Selection is sufficiently intense to produce intrapopulational differentiation.
\end{abstract}

\section{INTRODUCTION}

The thistle Cirsium palustre (L.) Scop. is typically purple flowered. However, populations occasionally contain white and intermediate flowered forms in high frequency, and this variation provides a convenient material for the study of ecological genetics. The present paper describes the nature, inheritance and distribution of the polymorphism; the selective effects of climate and population size; and the occurrence of intrapopulational selection. A further paper (Mogford, 1974) will discuss the influence of discriminative pollination.

C. palustre occurs native in Europe and W. Asia, and has been introduced into the United States, Canada and Australia (Bentham, 1863; Fernald, 1933, 1935; Hultén, 1958; Gleason and Gronquist, 1963). It is normally biennial, producing in the first year a basal rosette of leaves and in the second year an upright flowering stem. In Britain the species is very common and occurs throughout a wide range of habitats from sea level to $800 \mathrm{~m}$; these include meadows, moorland, forest clearings and seacliffs. The populations vary greatly in size and discreteness. On seacliffs the species is commonly found as fairly discrete populations of several hundred individuals, whereas larger and more diffuse populations are characteristic of damp, sheep-grazed meadows, where the species frequently becomes established as a difficult weed. Reproduction appears to be entirely by seed.

\section{THE POLYMORPHISM}

The flower colour variation was regarded as tomprising the following four categories:

Purple. Stigma and corolla lobes dark reddish purple. Androecium dark bluish purple. Style and corolla "throat" normally tinged light reddish purple. Corolla lobe pigment especially intense at tips.

Intermediate. Stigma and corolla lobes pink-purple. Androecium light bluish purple. Style normally white, corolla "throat" normally only slightly tinged pink-purple. Corolla lobe pigmentation normally very uniform. 
Purplish White. Stigma and corolla lobes only very lightly tinged pinkpurple. Androecium with a very light bluish purple region beneath the tip. Style white, corolla "throat" normally white. Corolla lobe pigment frequently restricted to immediately beneath tip.

White. No trace of colour anywhere within the floret. Stigma and androecium creamish white, remainder of floret white.

In plants of each flower colour type there normally occurred at least some purple pigmentation of the stem and leaves. The degree of such pigmentation was to some extent correlated with the degree of floral pigmentation, but this association was by no means absolute and for scoring purposes only flower colour was considered.

Only the white category appeared phenotypically and genetically uniform for flower colour; each of the other categories displayed variation and occasional plants were encountered whose classification was uncertain. Certain members of the purplish white category were completely white except for slight purple pigmentation of the upper regions of the androecia. In certain populations classification of the purple type was not clear, either

TABLE 1

Morph frequencies of populations referred to in text

\section{Population}

Clyne Common

Penmaen Marsh

Bishopston Valley

Cantref

Forest Lodge

$\begin{array}{ccc}\text { Grid } & \text { Year of } & \text { Sample } \\ \text { reference } & \text { scoring } & \text { size } \\ \text { SS 591895 } & 1969 & 137 \\ \text { SS 526885 } & 1969 & 235 \\ \text { SS 568880 } & 1969 & 50 \\ \text { SN } 992168 & 1971 & 699 \\ \text { SN } 961247 & 1971 & 356\end{array}$

\begin{tabular}{|c|c|c|c|}
\hline \multicolumn{4}{|c|}{ Morph Percentages } \\
\hline $\mathbf{P}$ & Int & ppW & Wh \\
\hline $77 \cdot 4$ & $11 \cdot 7$ & $2 \cdot 2$ & 8.7 \\
\hline 53.6 & $1 \cdot 7$ & 0.8 & 43.8 \\
\hline $4 \cdot 0$ & $92 \cdot 0$ & $4 \cdot 0$ & 0.0 \\
\hline $74 \cdot 5$ & $0 \cdot 0$ & $0 \cdot 0$ & $25 \cdot 5$ \\
\hline $36 \cdot 0$ & $0 \cdot 0$ & $0 \cdot 0$ & $64 \cdot 0$ \\
\hline
\end{tabular}

because the "purple" flowers possessed a low intensity of pigmentation, or because pigmentation was restricted to a high intensity purple colouration of the tips of the corolla lobes and the regions immediately beneath the tips of the androecia. However, the great majority of the plants encountered could be classified clearly into the above categories, which were therefore considered sufficiently distinct to be regarded as morph types in the sense of Ford (1940).

Taxonomically the white flowered individuals have been recorded variously as varieties albiflora (De Wildeman and Durand, 1998-1907), ferox Dr. (Druce, 1911) and alba (Druce, 1930; Horwood and Noel, 1933). Druce described the variety ferox $\mathrm{Dr}$. as possessing white or pale red flowers together with lighter green leaves, stronger and more numerous spines and a more condensed inflorescence than the type. It is likely, however, that he did not regard flower colour as a definitive criterion of the variety since later (Druce, 1930) he regarded the species as possessing both varieties ferox Dr. and alba. Similarly Druce (191l) regarded the variety ferox Dr. as likely to be equivalent to the Spanish variety spinosissimum Willkom. whereas flower colour is not listed as a character of that variety (Willkomm and Lange, 1861-93). During the present work examination of plants growing in a wide range of habitats has indicated that in seacliff and mountain habitats where the white morphs are most frequent the plants are indeed more compact and spinous than in other habitats, but no evidence is available that within a 
population the colour types differ in any respect other than pigmentation. Plants of different colour types from the Gower Peninsula were found to possess a uniform diploid chromosome number of 34 , the number constantly recorded by other workers using Continental material (Poddubnaja, 1931; Tischler, 1934; Rohweder, 1937; Czapik, 1958; Lövkvist, 1962; Moore and Frankton, 1962; Gadella and Kliphuis, 1963, 1966).

\section{Genetics}

Breeding experiments were performed on plants derived from two populations on the Gower Peninsula, located on Clyne Common and Penmaen Marsh. In addition, plants were grown in cultivation from seeds

TABLE 2

Breeding results

(1) Artificial pollinations

\begin{tabular}{|c|c|c|c|c|c|c|}
\hline \multirow[b]{2}{*}{ Population } & \multirow[b]{2}{*}{ Pollination } & \multirow{2}{*}{$\begin{array}{l}\text { No. of } \\
\text { crosses }\end{array}$} & \multicolumn{4}{|c|}{ Progeny ratio } \\
\hline & & & $\mathbf{P}$ & Int & $\mathrm{ppW}$ & Wh \\
\hline \multirow{3}{*}{ Clyne } & Purple, selfed & 1 & 12 & 0 & 0 & 0 \\
\hline & & 1 & 13 & 5 & 0 & 0 \\
\hline & & 1 & 2 & 0 & 0 & 2 \\
\hline \multirow[t]{4}{*}{ Clyne } & Intermediate, & 1 & 3 & 24 & 0 & 24 \\
\hline & selfed & 1 & 55 & 40 & 0 & 39 \\
\hline & & 1 & 7 & 9 & 0 & 6 \\
\hline & & 1 & 12 & 4 & 0 & 12 \\
\hline Clyne & White, selfed & 4 & 0 & 0 & 0 & 98 \\
\hline Clyne & $\begin{array}{l}\text { Purple female } \times \\
\text { White male }\end{array}$ & 5 & 23 & 0 & 0 & 7 \\
\hline Penmaen Marsh & $\begin{array}{l}\text { Purple female } \times \\
\text { White male }\end{array}$ & 1 & 11 & 0 & 0 & 0 \\
\hline \multirow[t]{2}{*}{ Clyne } & White female $\times$ & 4 & 19 & 0 & 0 & 35 \\
\hline & Purple male & 1 & 9 & 0 & 14 & 1 \\
\hline Penmaen Marsh & White female $x$ & 2 & 24 & 0 & 0 & 34 \\
\hline
\end{tabular}

(2) Natural pollinations

\begin{tabular}{llrrrrr} 
Bishopston & Purple & 1 & 11 & 7 & 0 & 0 \\
Valley & Intermediate & 4 & 3 & 169 & 18 & 6 \\
\multirow{3}{*}{ Penmaen Marsh } & White & 1 & 0 & 24 & 34 & 12 \\
& Purple & 8 & 59 & 0 & 0 & 9 \\
& Intermediate & 1 & 2 & 1 & 0 & 0 \\
& White & 3 & 26 & 1 & 0 & 62
\end{tabular}

set in natural conditions in the latter population and in a population in the Bishopston Valley. The morph frequencies of the populations and the results obtained are listed in tables 1 and 2.

Pollinations were performed by brushing together pollen laden inflorescences over consecutive days, transparent cellophane bags being used to exclude insects. The floral mechanism did not allow emasculation, and accordingly since the species is moderately self compatible (Mogford, 1974) it is likely that some of the progeny of cross-pollinated inflorescences were the result of self pollination. For this reason, and because of the size and long life-cycle of the species, the results are inconclusive but are recorded here since they are of relevance to the later discussion. 
Seeds were germinated on moist filter paper and the seedlings grown on in a greenhouse and finally in experimental beds; in these conditions mortality was low and accordingly selection was considered negligible. No developmental influence on colour production was apparent; plants induced to flowering during winter by extended illumination in a warm greenhouse produced flowers of the normal colour types expected from their parentage. In addition the plants grown from seeds set naturaliy in the two wild populations possessed morph frequency values which coincided closely with those of the original populations, for both sets of progeny, thereby suggesting that the environmental differences between these populations were not sufficient to produce developmental differences in pigment production.

Self-pollination of white plants yielded exclusively white progeny, indicating that the plants were homozygous. Self-pollination of purple plants indicated that one parent was possibly homozygous, while two were heterozygous and were perhaps themselves different. The two intermediate plants from Clyne Common whose selfed progeny were raised in large numbers were both heterozygous but yielded different progeny ratios; the lighter parent yielded a lower proportion of purples. The progeny derived from natural pollination of intermediate plants in the Bishopston Valley were themselves mostly intermediate, which since this population was composed mainly of intermediate plants would imply that at least a proportion of the parental plants was homozygous.

It would therefore appear that the purple and intermediate phenotypes each represent both homozygous and heterozygous conditions. The data indicate that the white phenotype represents a homozygous condition and are not inconsistent with this being a homozygous recessive. It is clear that the polymorphism involves more than one gene pair but the number of crosses so far available is insufficient for more precise analysis.

\section{Distribution}

A survey of floras revealed that the white-flowered plants occur widely throughout the British Isles and are present also in Belgium (De Wildeman and Durand, 1898-1907), France (Rouy, 1905), Italy (Fiori, 1969), Portugal (Sampaio, 1946) and Switzerland (Schinz and Keller, 1905-8). Salter (1928) and Cadbury (in Perring, F., ed., 1970) both recorded that in Wales the white-flowered plants were relatively more common at higher altitude. In all the Continental floras examined the white plants were stated to be infrequent, though populations containing up to 35 per cent whites have been recorded by the author in the Apuan Alps.

Explanation

Figs. 1-6.-Distribution of the polymorphism

Individual populations are represented by circles, related in size to population size and divided into sectors proportional in area to the frequency of the different morph types.

$\begin{array}{cc}\text { Population Size } & \text { Circle Size } \\ 150 \text { or less } & \text { small } \\ 151-500 \text { inclusive } & \text { medium } \\ \text { more than } 500 & \text { large }\end{array}$

Dotted lines represent $1000 \mathrm{ft}$ contour. Forest populations denoted by " $f$ ".

Morph Type
white
purplish white
intermediate
purple

Sector white lightly stippled heavily stippled black 
Recordings were taken of the frequencies of the different morph types in each of 300 populations located throughout a wide area of England and Wales, observations being concentrated in particular on the inland populations of North Wales and southern Mid Wales, and the coastal populations
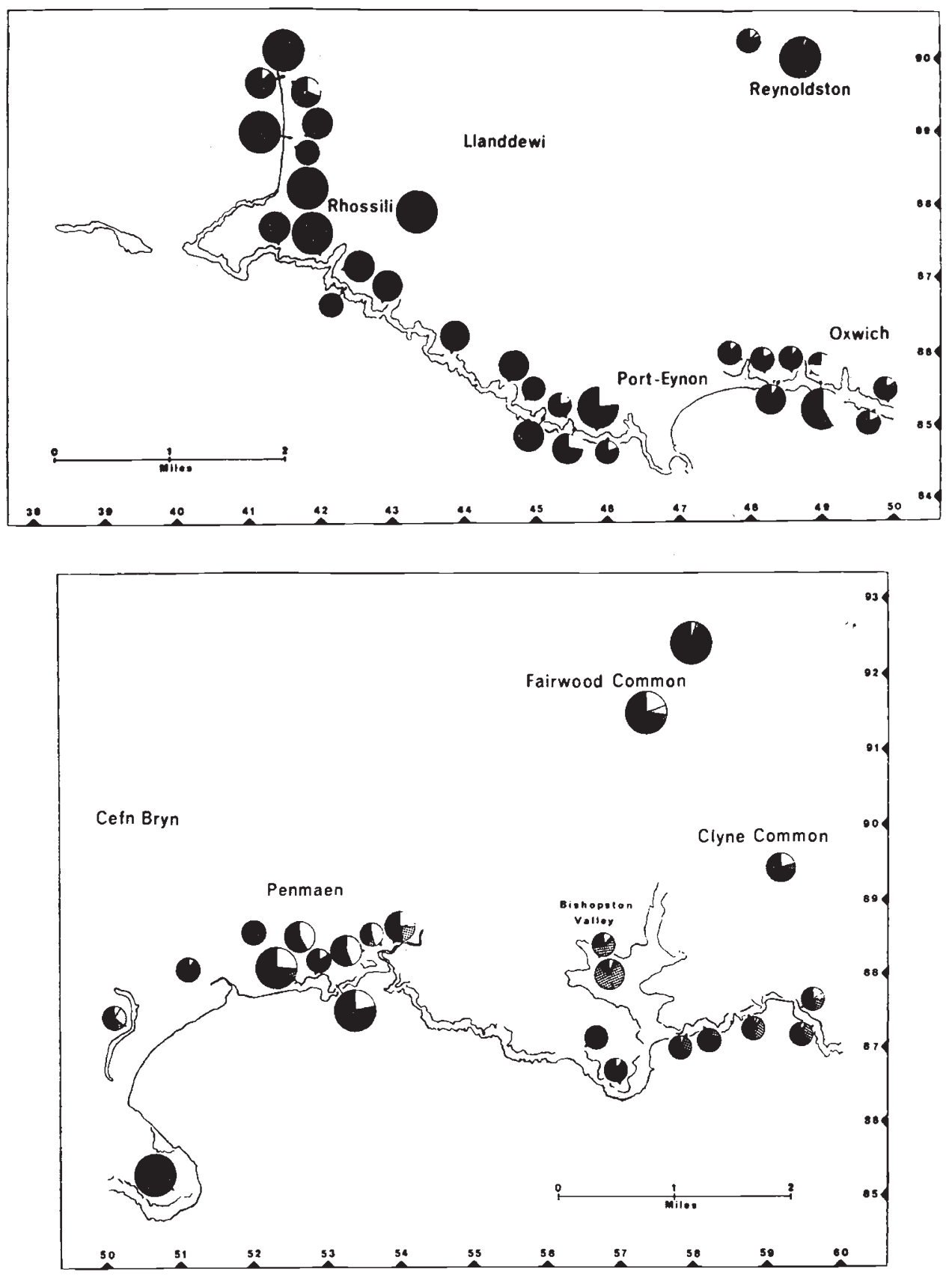

FIGs. 1 and 2.-Distribution of the polymorphism along the southern border of the Gower Peninsula, from Rhossili to Oxwich (above) and Oxwich to Clyne (below).

$33 / 2-Q$ 
D. J. MOGFORD
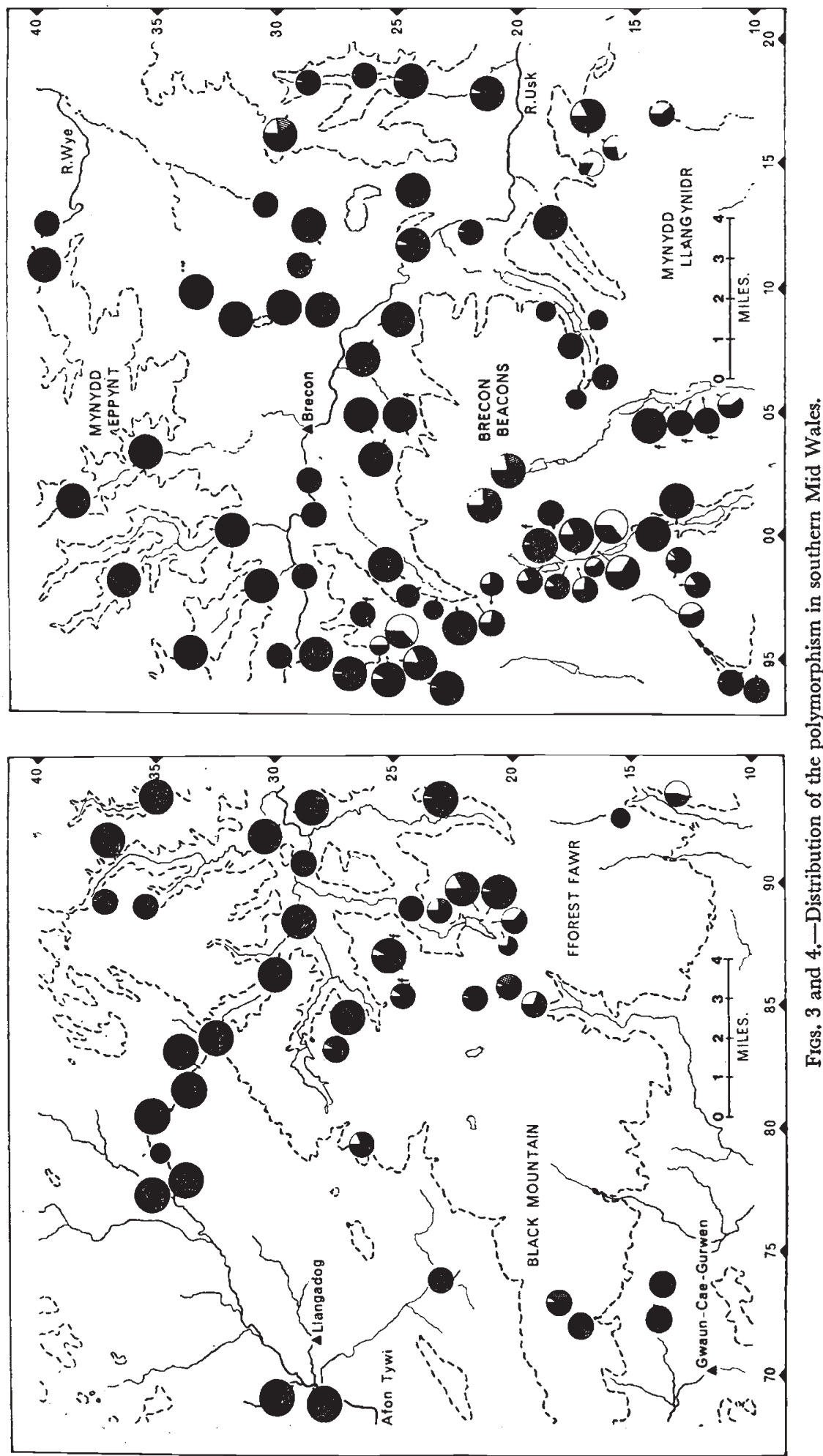

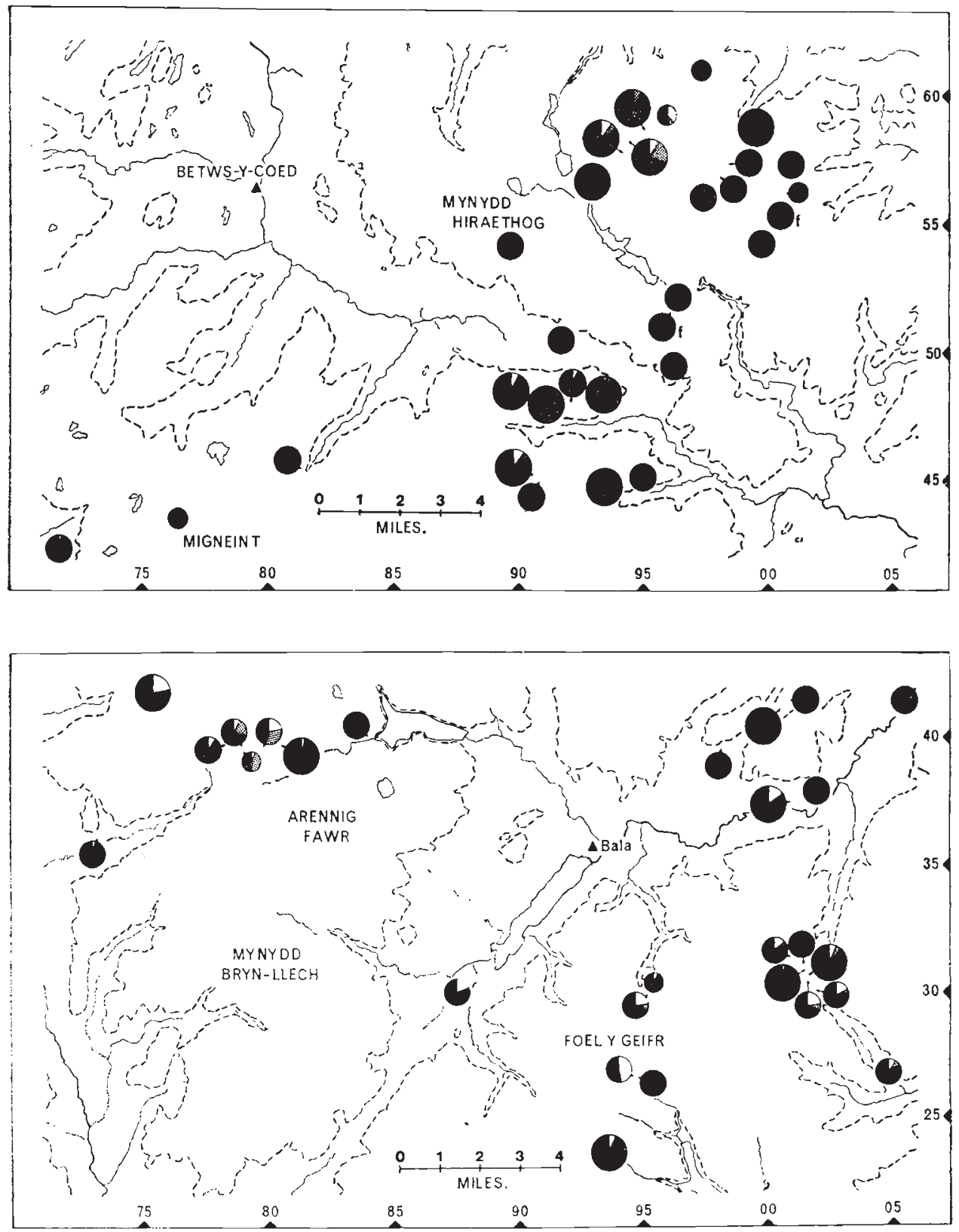

FIGs. 5 and 6.-Distribution of the polymorphism in North Wales.

of the Gower Peninsula and Pembrokeshire. In almost all cases at least 100 plants per population were scored. The results have been listed previously (Mogford, 1972).

Maps are provided of the distribution of the polymorphism in the Gower Peninsula, southern Mid Wales and North Wales (figs. 1-6). In South and Mid Wales the polymorphism was almost completely restricted to the 
populations of seacliffs and to those of mountain regions above $1000 \mathrm{ft}$. Above this altitude only forest populations possessed a low degree of polymorphism. Among mountain populations in North Wales the distribution pattern was very similar but slightly less precise, in that three populations of lowland valley regions were moderately polymorphic, and that even excluding forest populations predominantly purple populations were still common at altitudes above $1000 \mathrm{ft}$. Populations along the southern border of the Gower Peninsula showed some evidence of a cline in white frequency, those populations on the west of the peninsula containing lower proportions of the white morphs than those on the east.

Figure 7 illustrates the relationships between morph frequency and altitude for all the South and Mid Wales populations considered together. It may be seen that in general increase in white frequency was accompanied by decrease in purple frequency, and that the distribution of intermediates appeared likely to be unimodal. Comparison of these graphs with the distribution maps reveals that the relationships between morph frequency and altitude were more precise at the local level than for the total populations of each region considered together; however, linear regression analyses of angularly transformed values of white frequency upon altitude for populations above $1000 \mathrm{ft}$ were significant for both the southern Mid Wales populations ( $P=0.05-0.01)$ and for those of North Wales ( $P=0.01-0.001)$.

(7a) White Morphs

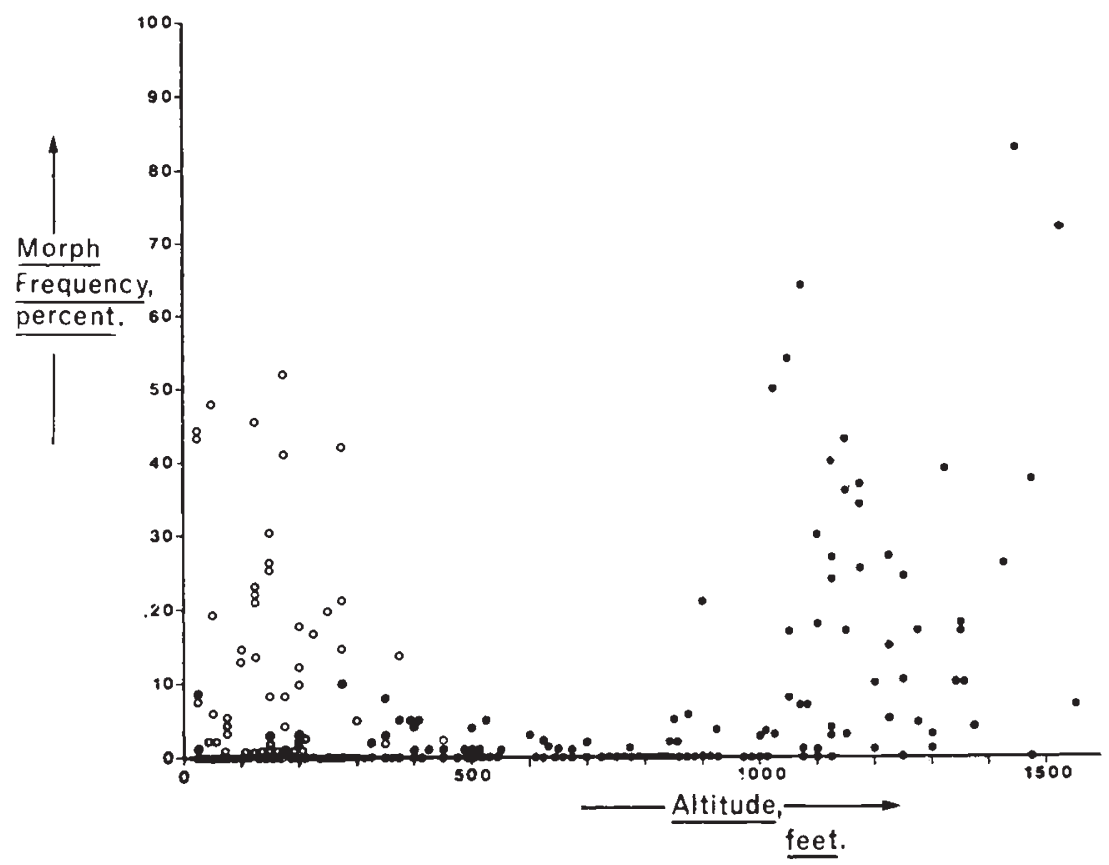

Fig. 7.-Variation in morph frequency with altitude for the populations of South and Mid Wales. Closed symbols represent inland populations; open symbols represent coastal populations. 
(7b) Intermediate Morphs

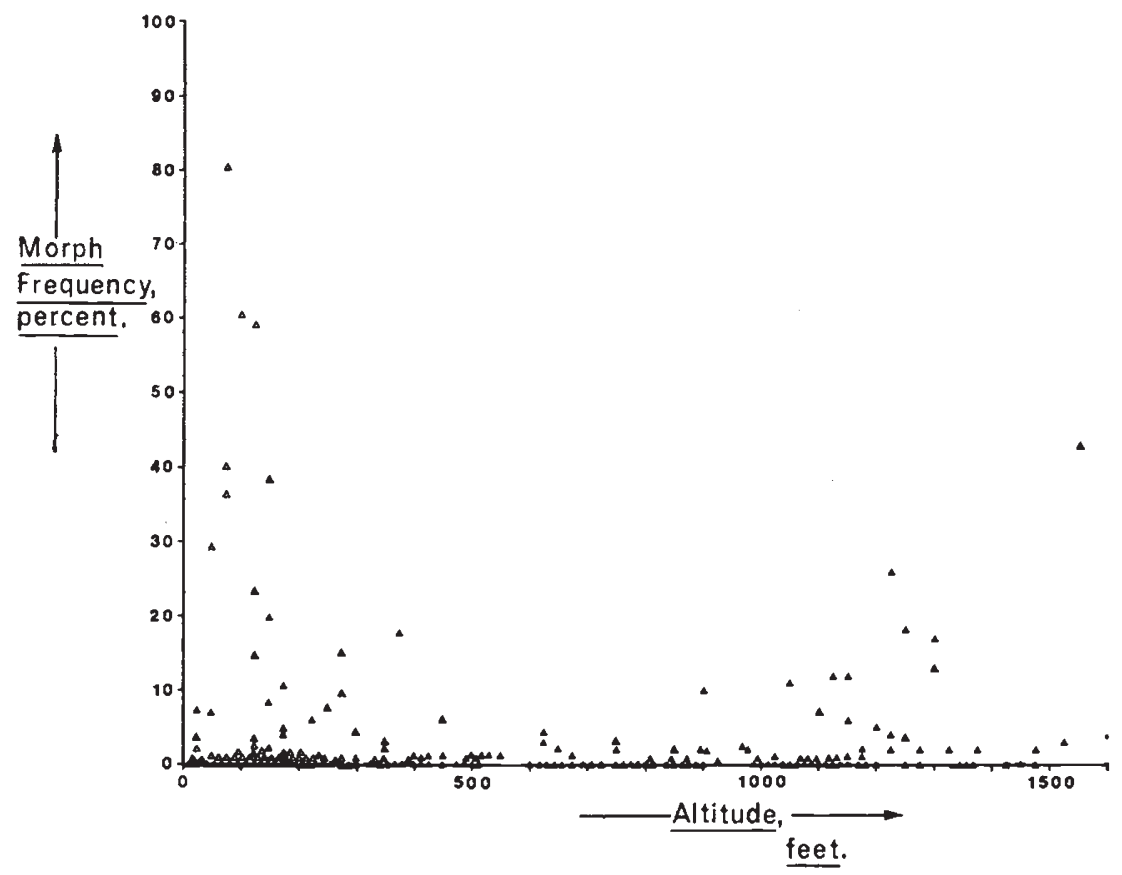

(7c) Purple Morphs

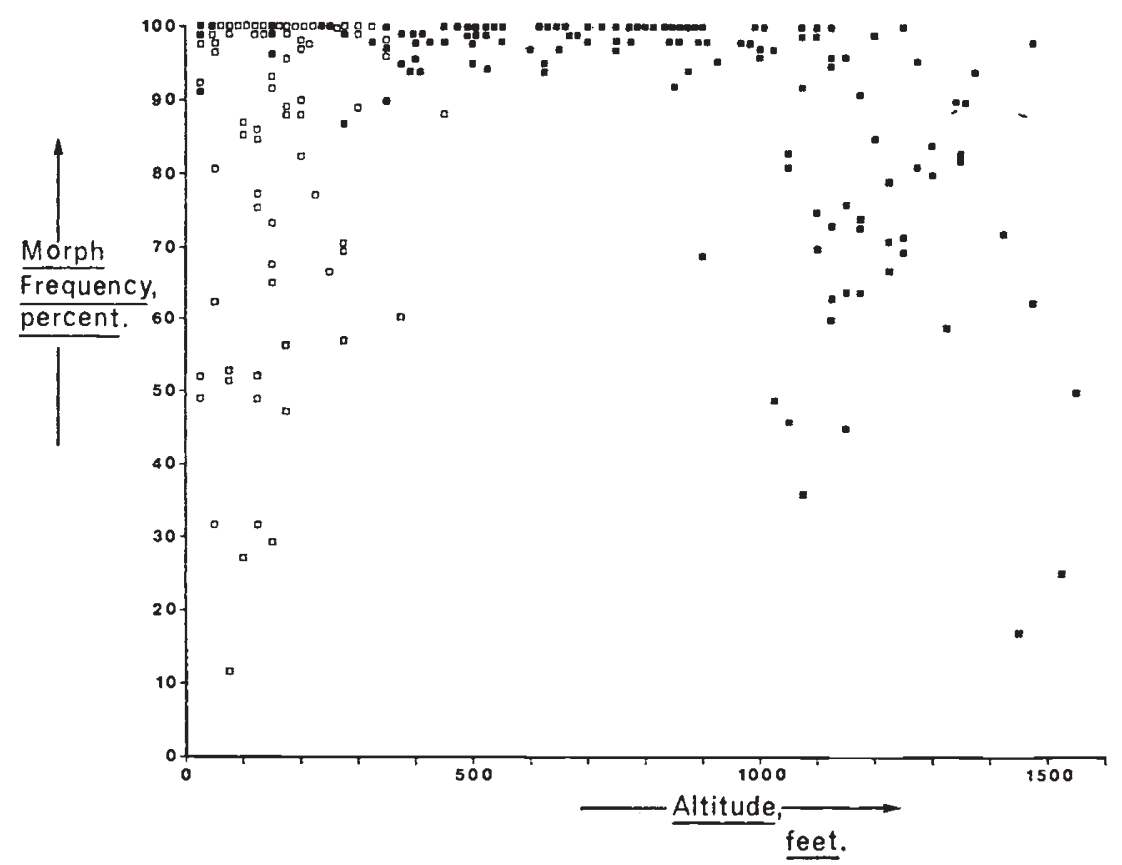




\section{Glimate}

Seacliffs and mountains are climatically distinct both from their surrounding regions and from each other. In general, increase in altitude is associated with a lowering of temperature and higher degrees of exposure, rainfall, mist and snow. In contrast, seacliffs possess much shorter periods

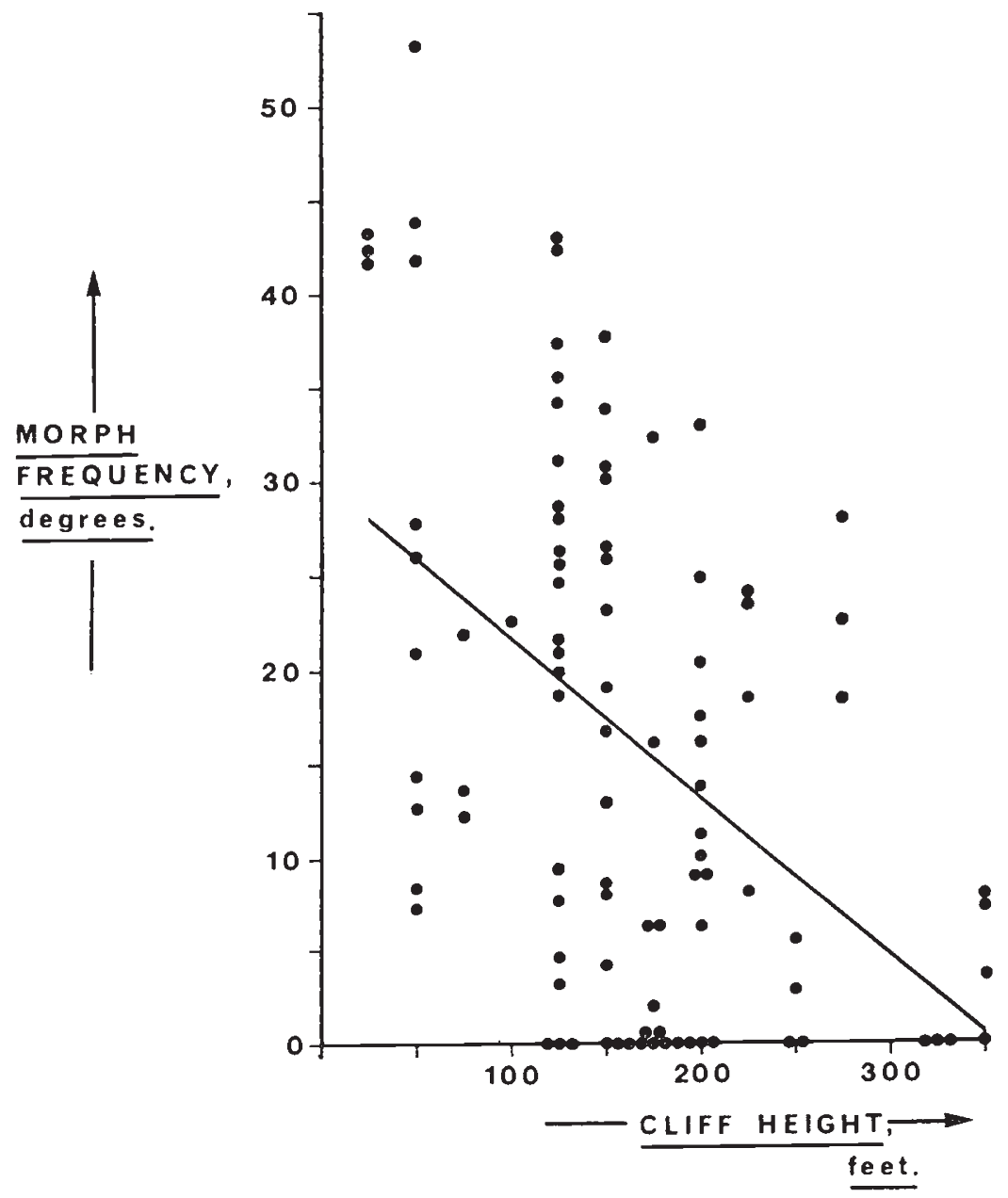

FIG. 8.-Variation in the frequency of white morphs with cliff height for Gower seacliff populations. Frequency values transformed by arcsine. (White frequency, degrees) $=$ $30 \cdot 1509-(0 \cdot 0852 \times$ Cliff $\mathrm{Ht}, \mathrm{ft}$.

of exposure to frost and much smaller amounts of rain (Meteorological Office, 1952). The incidence of sea-fog on seacliffs is unlikely to produce a marked resemblance between seacliffs and mountains with respect to mist, but the maintenance of high humidity on the cliff faces as a result of sea-spray might possibly bear resemblance to that maintained on mountains during mist and rain. However, perhaps the only significant climatic resemblance between seacliffs and mountains is the high degree of exposure to which both are subject. 
Evidence for the importance of exposure derives from the observation noted above that along the southern border of the Gower Peninsula the frequency of the white morphs was broadly clinal, being in general lowest on the western side and increasing eastwards. This variation relates to the expected variation in exposure along the peninsula, since the western cliffs would be expected to be the most exposed both by virtue of proximity to the tip of the peninsula and by being of greater height than those to the east.

Figure 8 illustrates the relationship between cliff height and white frequency for all the scorings of Gower seacliff populations made over a four-year period which related to populations over 75 in size. Analysis of this relationship by linear regression indicated an inverse relationship significant at the 0.1 per cent level. The square of the correlation coefficient

TABLE 3

Differences in the frequency of white morphs between segments of population subject to differing exposure

Segment

Morph ratio
(1) More exposed

$\overbrace{\mathrm{P} \quad \mathrm{I} \quad \mathrm{ppW} \quad \mathrm{W} \quad{ }_{n}}$



$\overbrace{\mathbf{P} \quad \mathrm{I} \quad \mathrm{ppW} \quad \mathrm{W} \quad{ }_{n}}$

(a) Overton Heath population (SS 458849)

$\begin{array}{lrlrrrrrrrr}1968 & 91.3 & 0.0 & 0.0 & 8.7 & 69 & 46.4 & 0.0 & 0.0 & 53.6 & 291 \\ 1969 & 89.6 & 0.0 & 0.0 & 10.4 & 48 & 67.6 & 1.9 & 0.0 & 30.5 & 105 \\ 1970 & 100.0 & 0.0 & 0.0 & 0.0 & 21 & 62.3 & 0.0 & 0.0 & 37.7 & 53 \\ 1971 & 88.7 & 0.0 & 0.0 & 11.3 & 142 & 69.0 & 0.0 & 0.0 & 31.0 & 593\end{array}$

(b) Oxwich Head population (SS 509850)

$\begin{array}{lrllllllllr}1968 & 97 \cdot 8 & 1 \cdot 0 & 1.0 & 0.2 & 409 & 67 \cdot 3 & 6.6 & 0.0 & 26 \cdot 0 & 196 \\ 1969 & 98 \cdot 7 & 0.3 & 0.0 & 0.9 & 318 & 73.0 & 5 \cdot 8 & 0.0 & 21 \cdot 2 & 189 \\ 1970 & 100 \cdot 0 & 0.0 & 0.0 & 0.0 & 180 & 81 \cdot 8 & 0.0 & 0.0 & 18.2 & 11 \\ 1971 & 99.4 & 0.2 & 0.4 & 0.0 & 549 & 86.7 & 0.0 & 0.0 & 13.3 & 15\end{array}$

(c) Stackpole Head population (SR 988948)

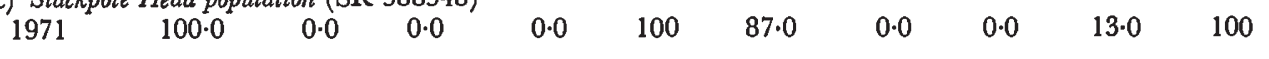

(d) Mynydd Troed population (SO 170295)

$\begin{array}{lllllllllll}1968 & 69.7 & 18.3 & 1.4 & 10.6 & 142 & 51.3 & 20.7 & 0.5 & 27.5 & 193\end{array}$

Morph frequency values presented as percentages, $n$ indicating sample size.

indicated that 22 per cent of the variance in white frequency could be attributed to cliff height alone. If it is accepted that exposure is the principal factor likely to be correlated with cliff height, then this would imply that exposure is a selective factor of considerable importance.

The influence of exposure was examined also at the intrapopulational level (table 3). The populations studied comprised three seacliff populations and a mountain population on Mynydd Troed. For each population the proportion of white morphs was compared between two segments differing in exposure, the comparisons being performed using $\chi^{2}$ or, for ratios containing values of 5 or less, Fishers exact test. It was found that in each population, on each season of scoring, the proportion of white morphs was significantly higher in the less exposed segment $(P<0.01$ in each case).

On mountains the most conspicuous feature of the distribution of the polymorphism was the abruptness with which highly polymorphic populations appeared at a certain altitude. Such abruptness might in the first 
instance be assumed to imply a sudden climatic discontinuity. However, the demonstration by Creed et al. (1959) that different spot stabilisations in the butterfly Maniola jurtina may be maintained in similar habitats on either side of a hedge illustrates that obvious ecological heterogeneity is not a precondition for biological divergence. However, it is relevant that in the regions considered altitudinal variation in climate is in fact very considerable; and indeed the increased climatic rigour at the level at which the white morphs first attain high frequency is illustrated by the approximate coincidence of this level with the upper limit of ground enclosure by farmers.

The distribution pattern of the polymorphism on mountains suggests first that temperature may be important. A hypothesis that low temperatures favour the existence of polymorphic populations would not only explain the overall presence of the polymorphism on mountains, but might also explain the occasional presence of highly polymorphic populations at low altitude in valley bases, and the apparently regular occurrence of predominantly purple populations in forest conditions at high altitude. For in valley bases it would be expected that low night temperatures would exist which might be more similar to those of mountains than to those of the immediate surrounds (Geiger, 1950); while in the enclosed interiors of upland forests comparatively high night temperatures might be maintained which would be relatively more similar to those of lowland regions.

However, it is equally possible that other factors may be important. Rainfall and mist increase with altitude, and together with low temperature are likely to be of particular importance in the limiting of pollination (Mogford, 1974). It is possible that the occurrence of cloud might be such as to produce particular increase in the amounts of rain and mist at the heights at which the polymorphism becomes frequent. Unfortunately the limited data available do not provide precise information on the frequency distribution of cloud base heights (e.g. High Wycombe Terminal Forecast Facility, 1961; Meteorological Office, 1952).

Finally may be considered the observation that in North Wales predominantly purple populations may be common at higher levels than in Mid Wales. Such difference in altitudinal limits may be compared with the data of Burkill and Willis (1894) and Salter (1928) which indicate that in general the altitudinal range of a species will be higher in mountain ranges of great height than in those of lesser height. It is possible that both these data and the present effect may be consequences of the greater sheltering effects provided in higher mountain ranges, in the present case the North Wales range. Certainly the North Wales mountains are known to produce considerable sheltering effects and typical Foehn winds (Lockwood, 1962). The further study of morph distribution in relation to topography may provide additional evidence on the factors maintaining the polymorphism.

\section{Population size}

The morph frequencies and numerical size of each of 45 Gower seacliff populations were scored on each of the four seasons 1968-71. These populations were suited to such scoring since they were mainly sufficiently discrete to allow population limits to be judged with accuracy. The results have been listed previously (Mogford, 1972).

The populations were mainly of the order of a few hundred individuals, 
a restricted size range which revealed no clear relationship between absolute population size and morph frequency. However, the populations were subject to very considerable size fluctuation, such that even large populations were occasionally reduced to a few individuals, and accordingly attention was devoted to the morph frequency changes accompanying such fluctuations.

For each morph type the number of instances in which, of two successive years, the year with the largest population size also possessed the higher morph frequency was compared to that in which the year with the largest population size possessed the lower morph frequency. The results, which are shown in table 4, are rather inconclusive when considered for each morph

TABLE 4

Morph frequency changes accompanying fluctuations in population size of Gower seacliff populations

\begin{tabular}{|c|c|c|c|}
\hline \multirow[b]{2}{*}{ Morph type } & \multicolumn{2}{|c|}{ Morph frequency change } & \multirow{2}{*}{$\begin{array}{l}\text { Probability } \\
\text { value }\end{array}$} \\
\hline & Increase & Decrease & \\
\hline Purple & 68 & 53 & $0 \cdot 20-0 \cdot 10$ \\
\hline Intermediate & 36 & 47 & $0 \cdot 50-0 \cdot 20$ \\
\hline Purplish White & 23 & 40 & $0.05-0.02$ \\
\hline White & 53 & 66 & $0 \cdot 50-0 \cdot 20$ \\
\hline Non-Purple morphs combined & 112 & 153 & $0.02-0.01$ \\
\hline
\end{tabular}

Morph frequency changes indicate the number of changes of each type (increase or decrease) that accompanied the direction of a decrease in population size. Probability values (calculated from $\chi^{2}$ ) indicate the significance of the departure of the increase: decrease ratio from unity.

type individually, although they tend to suggest that a population during its larger years will possess a lower frequency of the purple morph type and a higher frequency of each of the other types. When the results for the nonpurple morphs are combined then this trend is clearly significant.

The direction of such difference is the reverse of that which would be indicative of a drift effect involving fixation of the white morph type at low values of population size; rather it suggests a selective effect. The selective effects accompanying changes in population size are potentially complex. In particular, however, it is possible that numerical increase might be associated with a relaxation in selection for certain characters, and vice versa (Ford, 1964). Thus Ford and Ford (1930) noted an increase in the general variability of the butterfly Melitaea aurinia during a period of rapid numerical increase and attributed this to relaxed selection during this period. Such an explanation might well apply to the present results, increase in the frequency of the white morphs being promoted by a relaxation in selection during population expansion.

\section{INTRAPOPULATIONAL DIFFERENTIATION}

Seacliff populations of dissimilar morph frequency were commonly as close as 500 metres, over which distance pollen transport by bees and seed dispersal by wind could certainly operate (Rau, 1924; Butler, 1954; Free and Butler, 1959). This implied that the maintenance of the morph 
frequency values involved the regular operation of selection. Selection of this type would be expected to be most intense in instances of intrapopulational differences in morph frequency. Four cases have already been described in which intrapopulational differences in morph frequency occurred between segments of population subject to differing exposure. However, it was considered that such differences might be revealed even within populations of no obvious heterogeneity in morph frequency or environmental conditions if morph arrangement was studied in detail.

The criterion used was the degree of clumping, which was measured and compared between morph types in each of two populations. Whereas morph types may be clumped relative to each other as a result of seed dispersal alone, significant differences between the degrees of clumping of morph types may be explained only on a basis of differences between the morphs which may be assumed to be selective differences. The populations were at Cantref and Forest Lodge, both being mountain populations in Breconshire. Both were composed predominantly of purple and white morphs, with the latter occurring in high frequency (table 1). The populations were both located in grazed pasture, and each appeared extremely uniform both ecologically and in the apparent distributions of morph types.

The distributions of the morph types were measured and compared using the method of Pielou (1959). In each population measurements were taken from 100 points positioned using random number tables within a rectangular area enclosing several hundred plants. The method presents an index of association which, if significantly greater than unity, indicates clumping. The values obtained were, for the purple and white morphs respectively, 3.82 and 1.68 at Cantref, and 3.63 and 4.41 at Forest Lodge. The Cantref values were significantly different $(P=0.01-0.001)$, but those for Forest Lodge were not $(P>0 \cdot 10)$. It was concluded that at Gantref the morph types possessed differences in clumping of a type indicative of intrapopulational selection.

It was therefore clear that the selective status of the polymorphism was very far from that of near neutrality. The polymorphism exhibited clinal variation on the Gower Peninsula, possessed a precise relation to altitude, and was subject to selective forces associated with exposure and fluctuation in population size. Selection was sufficiently intense to produce intrapopulational differentiation, which occurred not only between regions of population of clear ecological dissimilarity, but extended to subtle differences in the distribution of morph types within a population of an apparently much greater ecological homogeneity.

Acknowledgments. - I wish to thank Professor C. D. Darlington and Professor F. R. Whatley for the provision of facilities at the Oxford Botany School. I am grateful to Dr S. R. J. Woodell and Dr Q. O. N. Kay for their advice during the research; to Dr L. P. Smith of the Meteorological Office, Bracknell, for guidance on climatic effects; and to Dr K. R. Lewis for reading the paper in manuscript. The work was financed by the N.E.R.G. and the Royal Society.

\section{REFERENCES}

Bentham, G. 1863-78. Flora Australiensis. Reeve, London.

BURKILl, J. H., AND WILlis, J. G. 1894. Botanical notes from north Cardiganshire. $\mathcal{J}$. Bot., Lond., 32, 4-10. 
BUTLER, C. G. 1954. The World of the Honeybee. Collins, London.

CREED, E. R., DOWDESWELL, W. H., FORD, E. B., AND MCWHIRTER, K. G. 1959. Evolutionary studies in Maniola jurtina: the English mainland 1956-57. Heredity, Lond., 13, 363391.

CZAPIK, R. 1958. Badania kariologiczne and polskimi gatunkami rodzaju Cirsium Mill. em. Scop. (Karyological studies in species of Cirsium Mill. em. Scop. occurring in Poland). Acta Soc. Bot. Pol., 27, 483-489.

de wildeman, E., ANd durand, Th. 1898-1907. Prodome de la Flore Belge. Castaigne, Brussels.

DRUCE, G. C. 1911. The international phytoleographical excursion in the British Isles. New Phytol., 10, 306-328.

DRUCE, G. c. 1930. The Flora of Northamptonshire. Buncle, Arbroath.

FERNALD, M. L. 1933. Recent discoveries in the Newfoundland flora. Rhodora, 35, 1-16, 364-386.

FERNALD, M. L. 1935. Critical plants of the upper Great Lakes region of Michigan. Rhodora, $37,324-341$.

FIoRI, A. 1969. Nuova Flora Analitica D'Italia. Edagricole, Bologna.

FORD, E. B. 1940. Polymorphism and taxonomy. The New Systematics (ed. J. Huxley). O.U.P., Oxford.

FORD, E. B. 1964. Ecological Genetics. Methuen, London, and Wiley, New York.

FORD, H. D., AND FORD, E. B. 1930. Fluctuation in numbers and its influence on variation in Melitaea aurinia. Trans, $R$. ent. Soc. Lond., 78, 345-351.

FREE, J. B., AND BUTLER, C. G. 1959. Bumblebees. Collins, London.

GADELla, T. W. J., AND KLIPHULS, E. 1963. Chromosome numbers of flowering plants in the Netherlands. Acta bot. neerl., 12, 195-230.

GAdElla, T. W. J., AND KLIPHUIS, E. 1966. Chromosome numbers of flowering plants in the Netherlands, 2. K. Akad. Wetenschap. Amsterdam Proc., Ser. C., 69, 541-556.

GeIGer, R. 1950. The Climate near the Ground. Harvard University Press, Cambridge, Mass.

GleAson, H. A., AND CRONQUTST, A. 1963. Manual of Vascular Plants of Northeastern United States and Adjacent Canada. Van Nostrand, Princeton, New Jersey.

HIGH WYCOMBE TERMINAL FORECAST FACILITY. 1961. Diurnal Variations of Ceiling and Visibility for Selected Air Bases in England. High Wycombe.

HORWOOD, A. R., AND NOEL, C. W. F. 1933. The Flora of Leicestershire and Rutland. O.U.P., Oxford.

HUltén, E. 1958. The Amphi-Atlantic Plants and their Phytogeographical Connections. Almqvist \& Wiksell, Stockholm.

LockwooD, J. G. 1962. Occurrence of föhn winds in the British Isles. Met. Mag., 91, $57-65$.

Lövkvist, B. 1962. A case of probable introgression in Cirsium. Bot. Notiser, 115, 385-386. MEteorological office. 1952. Climatological Atlas of the British Isles. H.M.S.O., London. MOGFORD, D. J. 1972. The Ecological Genetics of Flower Colour Variation in Cirsium palustre. D. Phil. thesis, University of Oxford.

MOGFORD, D. J. 1974. Flower colour polymorphism in Cirsium palustre. 2. Pollination. Heredity $33,257-263$.

MOORE, R. J., AND FRANKTON, c. 1962. Cytotaxonomic studies in the tribe Cynareae (Compositae). Can. F. Bot., 40, 281-299.

Perring, F. (ed.). 1970. The Flora of a Changing Britain. Pendragon Press, Middlesex.

PIELOU, E. C. 1959. The use of point to plant distances in the study of the pattern of plant populations. F. Ecol., 47, 607-613.

podpubnaja, v. 1931. Ein Versuch der Anwendung der embryologischen Methode bei der Lösung einiger systematischer Fragen. 1. Vergleichende embryologische-zytologische Untersuchungen über die Gruppe Cynareae, Fam. Compositae. Beih. bot. Zbl., 48, 141-237.

RAU, P. 1924. Notes on captive colonies and homing of Bombus pennsylvanicus De Geer. Ann. ent. Soc. Am., 17, 368-381.

ROHWEDER, H. 1937. Versuch zur Erfassung der mengenmässigen Bedeckung des Darss und Zingst mit polyploiden Pflanzen. Ein Beitrag zur Bedeutung der Polyploidie bie der Eroberung neuer Lebensräume. Planta, 27, 501-549.

Rovy, G. 1906. Flore de France. Asnières \& Paris.

SALtER, J. H. 1928. The altitudinal range of flowering plants and ferns in Mid Wales. The North Western Naturalist, 1928.

Sampaio, G. 1946. Flora Portuguesa. Moderna, Porto. 
SChinz, H., AND kEller, R. 1905-9. Flora der Schweiz. Raustein, Zurich.

TISCHLER, G. 1934. Die Bedeutungen der Polyploidie für die Verbreitung der Angiospermen erläutert an den Arten Schleswig-Holsteins, mit Ausblicken auf andere Florengebiete. Bot. $7 b ., 67,1-36$.

Willkomm, M., AND LANGe, J. 1861-93. Flora Hispanica. Schweizerbart, Stuttgart. 